Journal of Mathematics and Statistics 7 (2): 112-115, 2011

ISSN 1549-3644

(C) 2011 Science Publications

\title{
Research of Modular Object Oriented Dynamic Learning Environment E-Learning on Social Study for Elementary School Students
}

\author{
${ }^{1}$ Tian-Syung Lan and ${ }^{1,2}$ Shu-Chun Chiu \\ ${ }^{1}$ Department of Information Management, Yu Da University, \\ Miaoli County, 361, ROC, Taiwan \\ ${ }^{2}$ Office of Academic Affairs, Jiou-Hu Elementary School, \\ Miaoli County, 366, ROC, Taiwan
}

\begin{abstract}
Problem statement: As the progress of digital technology, involving e-learning into curriculum becomes a novel trend. In general, the teaching practice of social study for elementary school students in Taiwan still depends on teacher's one-way instruction. It's difficult to activate students' motivation within the limited course time. Approach: This study is proposed to recognize how e-learning improves teaching and learning in the domain of social study for elementary school students. The quasi-experimental method is basically introduced into this study. Additionally, two sample teams: experimental group (the team with MOODLE, Modular Object Oriented Dynamic Learning Environment, e-learning) and control group (the team with traditional teaching method) are arranged for this study. The resource in how e-learning will affect elementary school students in the field of social study is moreover received. Results: Through the computer-based statistical analysis, two points are furthermore concluded as 1. The average learning score from the experimental group exceeds that from control group. 2. The students in the experimental group have a positive attitude toward e-learning. Conclusion: It is shown that the e-learning integration into curriculum indeed helped students' performance. Besides, from the data of questionnaires, students with MOODLE elearning were more confident in self-studying and understanding of the course content.
\end{abstract}

Key words: E-learning, Computer Assisted Learning (CAL), Learning Management System (LMS), MOODLE, social study, quasi-experiment, Computer Assisted Instruction (CAI), Course Management System (CMS), Learning Management System (LMS), Virtual Learning Environment (VLE)

\section{INTRODUCTION}

Traditionally, the teaching curriculum, method and agenda depend on both students' learning situation and teachers' experience. However, this is often not able to take care of individual needs that will result to worse teaching effect. Compared with the conventional teaching skills, e-learning presents several more advantages, including low study cost, responsive enhancement, as well as individual and immediate teaching materials. Therefore, teaching by web or online resources is considered to be the trend.

The key to increase learning efficiency is the interaction between the teacher, students and teaching materials. According to Ian's research, the levels of students are related to the environment which a teacher creates (Rudolf and Griffiths, 2009). How the teacher apply the resources he or she has upon teaching is the most important subject to be considered. Most of the existing e-learning researches paid attention to high school students, college students and public figures. It is hardly found studies for the elementary school students. As the elementary school or middle school students gradually use computers more and more frequently, it is important to realize the influence of e-learning to the elementary school students. Recently, the MOODLE (Modular Object Oriented Dynamic Learning Environment) e-learning is functioned relatively well in teaching (Journell, 2010; Romero et al., 2009; Jabr and Omari, 2010 Abdellatief et al., 2011; Middleton, 2010; Ellis et al., 2009). Based on the viewpoints above, the influence of elementary school teachers to guide students in learning and building their knowledge through Internet and MOODLE is deemed necessary to be studied. Therefore, this study proposed to explore whether MOODLE e-learning is helpful and efficient for elementary school students in the domain of social

Corresponding Author: Tian-Syung Lan, Department of Information Management, Yu Da University, Miaoli County, 361, OC, Taiwan 
study. The result can be referenced by teachers for future teaching improvement.

\section{MATERIALS AND METHODS}

Jay Cross first led the trend about the importance of e-learning (Othman and Muhammad, 2011), where the rising development and computer web technology stimulate the combination of Computer Assisted Learning (CAL) and Computer Assisted Instruction (CAI) (Abdellatief et al., 2011). E-learning breaks the limitation of time and location with students learning from online resources. It also provides the choice for students to adjust their own learning schedules. On the other hand, a teacher can adjust his or her teaching pace. Due to the development of internet technology, elearning becomes the main stream of new teaching manner (Kramer and Bente, 2010).

Affected by the involvement of open sources, free software is more and more valuable. The free software means its openness for not only free of cost but also source codes. MOODLE (Modular Object Oriented Dynamic Learning Environment) is one of the free software which is a Course Management System (CMS), Learning Management System (LMS) or Virtual Learning Environment (VLE). MOODLE is designed with PHP to low technical threshold interface and obey the GNU General Public License (GPL) which can be used, extended and revised freely. MOODLE is based on the system of Social Constructionist Pedagogy (SCP). It expects that the members of a community to make efforts for the same goal and share the achievements. MOODLE reveals the advanced teaching idea for teachers to manage the curriculum and teaching activities. Besides, students can also learn whenever they want through the browser. It is noted that MOODLE is currently be utilized in 150 countries around the world under 70 different languages and more than 100,000 various groups of users registered to its website community (Fig. 1) (Bahrudin et al., 2011).

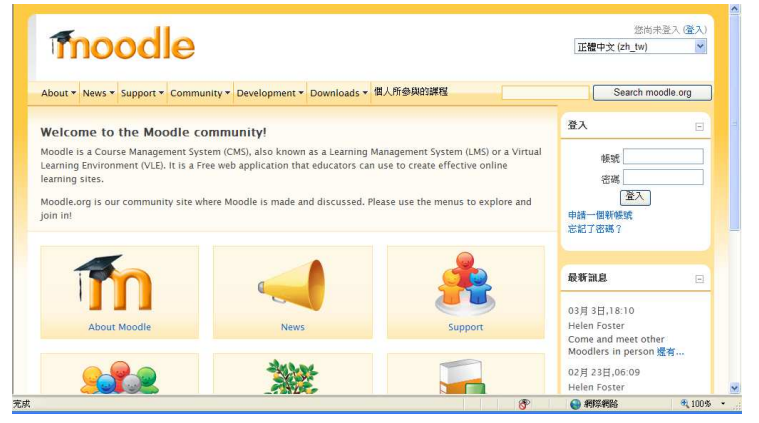

Fig. 1: Website of MOODLE
Participants: In this study, the subjects of this research are the 5th grade elementary students in two different classes. In the domain of social study, the control group (32 students) is taught by the traditional method, but the experimental group (30 students) is taught through Elearning.

Measures: The difference of learning efficiency and students' reactions from the two different groups are measured by two instruments as below.

Achievement test in social study: The test items were designed based on teaching curriculum. Fifty students at the $6^{\text {th }}$ grade who had learned this unit is examined as a pre-test. The items of difficulty above 0.25 and the discrimination between $0.4 \sim 0.8$ are selected and the inappropriate ones are deleted. The reliability coefficient of Cronbach's $\alpha$ has been confirmed to be 0.74 which revealed the test was in good internal consistency.

Students' questionnaire: There were twenty items in the questionnaire. One of them was open question and the others were using the five-point Likert's scale design, where 5 means "strongly agree", 4 means "agree", 3 means "no comment", 2 means "disagree" and 1 means "strongly disagree". Besides, the options were reversed in items No. 7 and 19.

Procedures: This study was quasi-experimental designed. The first unit of the 5th grade students' social study course was selected during the spring semester. The research has been lasted for four weeks. After the four week learning, a post-test was taken by the two different groups in order to compare the immediate difference in the effectiveness of students' learning. Besides, the experimental group was also required to fill out the questionnaire. Thus, their attitude and feelings can then be found.

Data analysis: This research intended to explore if there was significant difference between two groups in the learning effectiveness of social study. Moreover, we tried to get the picture how students in the experimental group felt about E-learning.

\section{RESULTS}

Result of social study achievement test: The statistics analysis of social study achievement test is shown in Table 1. The result of one-way ANOVA analysis is presented in Table 2. 
Table 1: Descriptive statistics analysis of the result

\begin{tabular}{|c|c|c|c|c|c|}
\hline \multirow[b]{2}{*}{ Test item } & \multicolumn{2}{|c|}{ The control group } & \multicolumn{3}{|c|}{ The experimental group } \\
\hline & Average & $\begin{array}{l}\text { standard } \\
\text { deviation }\end{array}$ & Average & $\begin{array}{l}\text { standard } \\
\text { deviation }\end{array}$ & $\begin{array}{l}\text { Mean } \\
\text { difference }\end{array}$ \\
\hline Final test & 82.92 & 13.92 & 86.88 & 12.9 & 3.96 \\
\hline
\end{tabular}

Table 2: One-way ANOVA analysis of the result

\begin{tabular}{|c|c|c|c|c|c|c|}
\hline \multirow[b]{2}{*}{$\begin{array}{l}\text { Test } \\
\text { item }\end{array}$} & \multicolumn{2}{|c|}{ The control group } & \multicolumn{4}{|c|}{ The experimental group } \\
\hline & Average & $\begin{array}{l}\text { standard } \\
\text { deviation }\end{array}$ & Average & $\begin{array}{l}\text { standard } \\
\text { deviation }\end{array}$ & $\mathrm{F}$ & $\mathrm{P}$ \\
\hline Final test & 82.92 & 13.92 & 86.88 & 12.9 & 6.78 & $0.01^{*}$ \\
\hline
\end{tabular}

Result of questionnaires: At the aspect of students' learning mood, $94.8 \%$ of the experimental group believes that introducing MOODLE e-learning into the teaching of social fields is fun and interesting and $90.8 \%$ of students felt more comfortable than the class taught by traditional instruction.

For learning situation, $95 \%$ of students feels that using media was easier to understand the content of learning. Nevertheless, there are $8.2 \%$ of students feels difficult. In addition, $96.3 \%$ of students is experienced by the images, words and videos presented in the media for deeper impression.

For the interaction of the teacher and students, only $18.3 \%$ of students considers less interactive with the teacher by using MOODLE e-learning. Up to $95.7 \%$ of students is expecting MOODLE e-learning into teaching for continuity.

\section{DISCUSSION}

In Table 1, it is realized that the total mean score of the control group is 82.92 and that of the experimental group is 86.88 at social study achievement test field. The average score of experimental group was 3.96 points higher than that of the control group. In Table 2, the independent variable (i.e., teaching method) has a significant difference on the dependent variable (i.e., the achievements in the field of social study) which caused by experimental treatments $(\mathrm{F}=6.78, \mathrm{P}=0.01$ $<0.05)$. It is noted that the experimental group who used MOODLE e-learning into learning for social fields has better performance than the control group.

\section{CONCLUSION}

The purpose of this study is to investigate how the integration of MOODLE e-learning for teaching differs from traditional teaching in learning effectiveness for the 5 th grade elementary students. The opinions and reactions from the experimental group about MOODLE e-learning have also been achieved. The result of this study showed that students learning from MOODLE had higher average score in the social study achievement test. It is shown that the e-learning integration into curriculum indeed helped students' performance. Besides, from the data of questionnaires, students with MOODLE e-learning were more confident in self-studying and understanding of the course content.

MOODLE e-learning platform needs timely effort to build up and maintain. It is suggested that a group of teachers can unite and cooperate as a course team to create and maintain this learning platform. This definitively provides diverse learning materials and enhances the learning achievement as well as the motivation of students.

\section{REFERENCES}

Abdellatief, M., A.B.M. Sultan, M.A. Jabar and R. Abdullah, 2011. A technique for quality evaluation of e-learning from developers perspective. Am. J. Econ. Bus. Admin., 3: 157-164. DOI: 10.3844/ajebasp.2011.157.164

Bahrudin, I.A., M. Muhammad, M.I.A. Nawawi, I.N. Saharudin and H.M. Din et al., 2011. Development of interactive courseware for learning basic computer system components. Am. J. Econ. Bus. Admin., 3: 132138. DOI: 10.3844/ajebasp.2011.132.138

Ellis, R.A., P. Ginns and L. Piggott, 2009. E-learning in higher education: Some key aspects and their relationship to approaches to study. Higher Edu. Res. Dev., 28: 303-318. DOI: 10.1080/07294360902839909

Jabr, M.A. and H.K.A. Omari, 2010. E-learning management system using service oriented architecture. J. Comput. Sci., 6: 285-295. DOI: 10.3844/jcssp.2010.285.295

Journell, W., 2010. Perceptions of e-learning in secondary education: A viable alternative to classroom instruction or a way to bypass engaged learning? Edu. Media Int., 47: 69-81. DOI: 10.1080/09523981003654985

Kramer, N.C. and G. Bente, 2010. Personalizing elearning. The social effects of pedagogical agents. Edu. Psychol. Rev., 22: 71-87. DOI: 10.1007/s10648-010-9123-x

Middleton, D., 2010. Putting the learning into Elearning. Eur. Political Sci., 9: 5-12. DOI: 10.1057/eps.2009.37 
Othman, Z. and A. Muhammad, 2011. Design strategies to persuasive learning for promoting sustainable practices in paddy farming. Am. J. Econ. Bus. Admin., $\quad 3$ : 197-202. DOI: 10.3844/ajebasp.2011.197.202

Romero, C., P. Gonzalez,S. Ventura, M.J. del Jesus and F. Herrera, 2009. Evolutionary algorithms for subgroup discovery in e-learning: A practical application using MOODLE data. Exp. Syst. Appli., 36: 1632-1644. DOI: 10.1016/j.eswa.2007.11.026
Rudolf, M. and Y. Griffiths, 2009. Evaluating the ergonomics of a student learning environment. Rehabilitation Assistive Technol., 34: 475-480. DOI: 10.3233/WOR-2009-0948 